\title{
Epidemiology and strategies for chemical management of powdery mildew in mango
}

\author{
Amado Pérez-Rodríguez ${ }^{(1)}$, Abraham Monteón-Ojeda(1), \\ José Antonio Mora-Aguilera ${ }^{(1)}$ and Elías Hernández-Castro(2)
}

\begin{abstract}
${ }^{(1)}$ Colegio de Postgraduados, Km 36.5, Carretera México-Texcoco, Caja Postal 56230, Montecillo, Estado de México, México. E-mail: perez.amado@colpos.mx, abraham_mojeda@hotmail.com, aguilera@colpos.mx (2)Universidad Autónoma de Guerrero, Unidad Académica de Ciencias Agropecuarias y Ambientales, Carretera Iguala-Tuxpan, Km 2.5, Caja Postal 40101, Iguala, Guerrero, México. E-mail: ehernandezcastro@yahoo.com.mx
\end{abstract}

\begin{abstract}
The objective of this work was to evaluate phytosanitary strategies for the chemical control of powdery mildew (Oidium mangiferae) in mango, based on the alternation of active ingredients with different modes and sites of action, and to determine the environmental and epidemiological conditions that favor the development of the disease. The experiment was conducted in Guerrero, México, in commercial orchards, within a program for the development of fungicide spraying strategies. Epidemic curves were used on temporal analyses of the disease for: incidence; area under disease progression curve (AUDPC); severity; and conidial seasonality and its relationships with meteorological parameters. The disease was better controlled with the application of systemic fungicide followed by contact fungicide with multisite activity. The first symptoms appeared 30 days after the issuance of shoots, and the most susceptible phenological (critical) stages were at full bloom and at the onset of fruit with $8-15 \mathrm{~mm}$. Optimum conditions for the development of powdery mildew, which maximizes the density of airborne spores, are temperatures higher than $30^{\circ} \mathrm{C}$ and relative humidity over $90 \%$.
\end{abstract}

Index terms: Mangifera indica, Oidium mangiferae, epidemics, fungicide resistance, integrated pest management, multisite fungicides.

\section{Epidemiologia e estratégias para o manejo químico do míldio-pulverulento em mangueira}

\begin{abstract}
Resumo - O objetivo deste trabalho foi avaliar estratégias fitossanitárias para o controle químico do míldioda-mangueira (Oidium mangiferae), baseadas na alternação de princípios ativos com diferentes modos e sítios de ação, e determinar as condições ambientais e epidemiológicas que favorecem o desenvolvimento da doença. O experimento foi realizado em Guerrero, México, em pomares comerciais, no âmbito de um programa para o desenvolvimento de estratégias de pulverização com fungicida. Curvas epidêmicas foram utilizadas em análises temporais da doença quanto à: incidência; área abaixo da curva de progresso da doença (AACPD); severidade; e sazonalidade dos conídios e sua relação com parâmetros meteorológicos. A doença foi mais bem controlada com a aplicação de fungicida sistêmico seguido de fungicida de contato, com atividade multissítio. Os primeiros sintomas apareceram 30 dias após a emissão dos brotos, e os estádios fenológicos mais sensíveis (críticos) foram o de floração completa e o de frutos com 8-15 mm. As condições ótimas para o desenvolvimento do oídio, que maximizam a densidade de esporos no ar, são temperatura acima de $30^{\circ} \mathrm{C} \mathrm{e}$ umidade relativa superior a $90 \%$.
\end{abstract}

Termos para indexação: Mangifera indica, Oidium mangiferae, epidemia, resistência a fungicidas, manejo integrado de pragas, fungicidas multilocais.

\section{Introduction}

Mango (Mangifera indica L.) is the third most important tropical fruit worldwide, after banana (Musa $s p$.) and orange (Citrus sinensis L.). México is the fifth producer worldwide and the first in exportation (FAO, 2016). Oidium mangiferae Berthet, the causal agent of powdery mildew in mango, is widely distributed throughout the Pacific region. The disease has been reported in many countries of Asia, Middle East, Africa, South Africa, America, and Oceania (Nasir et al., 2014). In México, the disease is widely distributed especially in the Pacific Coast and the severity has increased considerably in the last years (FélixGastélum et al., 2013). 
Powdery mildew is observed as a white powder, consisting of mycelium and conidia, on leaves, petioles, inflorescences, and fruit (Nelson, 2008). Mango is the only known host for the pathogen, which can have a sporadic, but very severe incidence, causing up to $90 \%$ crop loss (Nelson, 2008).

The pathogen develops in dry and cold environments, but reaches greater severity at $90 \%$ relative humidity (RH) and $20-25^{\circ} \mathrm{C}$ (Nasir et al., 2014). In Michoacán, the maximum severity of the disease coincides with periods of temperature of $13-20^{\circ} \mathrm{C}$ and $22-60 \% \mathrm{RH}$ (Guillén-Sánchez et al., 2003). The control is based mainly on fungicides, such as Carbendazim, Benomyl, and Thiabendazole, to which $O$. mangiferae had already developed resistance (Mora Aguilera et al., 2002; FRAC, 2012). In contrast, fungicide rotation with different sites of action, with molecules such as strobilurins (azoxystrobin and trifloxystrobin), anilinopyrimidines (cyprodinil), morpholines (fenpropimorph, fenipropidinspiroxamine), triazoles (myclobutanil, propiconazole, tebuconazole and Triadimefon), fenoxyquinolines (Quinoxyfen), and multisite fungicides (sulfur, dithiocarbamates and quinomethionates) can act efficiently and reduce the risk of appearance of fungal resistance (Margot et al., 1998; Reuveni \& Reuveni, 2002; Wicks \& Hitch, 2002).

Epidemiology can aid the efficient evaluation of management practices for diseases (Guillén-Sánchez et al., 2003, 2004). Epidemiological studies for specific production areas can help establish effective chemical control programs to be included in an integrated pest management program. Despite this, there are few epidemiological studies on powdery mildew on mango in México, with only one research (Téliz, 1998), made in Michoacán by the Interdisciplinary Research Group on Mango (GIIM Spanish acronym). However, there is no research on the subject in Técpan de Galeana (subhumid tropic), Guerrero, which is the main producing state in México.

The objective of this work was to evaluate phytosanitary strategies for powdery mildew chemical control, based on the alternation of active ingredients with different modes and sites of action; and to explain the temporal development of the pathogen based on flowering phenology, seasonal density of inocula, and on environmental factors.

\section{Materials and Methods}

The experiment was carried in an orchard, in Las Tunas $\left(17^{\circ} 16^{\prime} \mathrm{N}, 100^{\circ} 33^{\prime} \mathrm{W}\right.$, at $20 \mathrm{~m}$ altitude), Técpan de Galeana (subhumid tropic), Guerrero, México, with average annual precipitation and temperature of 1,525 $\mathrm{mm}$ and $27.1^{\circ} \mathrm{C}$, respectively (SMN, 2017).

The orchard is planted on a sandy loam red soil with 14-15 year-old 'Manila' mango, spaced at a 10x10 m arrangement. The study was conducted during the 2011-2012 cycles, within a program of agronomic management (PAM) to control mango diseases. This program was supplemented with fungicide application strategies, based on the use of different active ingredients, modes of action, and spray timing, aimed to control $O$. mangiferae. The PAM consisted of: sanitary pruning, soil and leaf chemical fertilization, weekly irrigations, and flowering stimulation $\left(\mathrm{KNO}_{3}\right.$, $2 \%)$.

Trees with similar trunk diameter and canopy volume were selected, treated, and evaluated. Three flowerings and vegetative flushes occurred during the experiment. Chemical control was done in the first and third flushes. The treatments were based on the rotation of fungicide active ingredients from different chemical groups and with different modes of action. Because the study was carried out in the field, in a commercial orchard, the treatments were inserted within an integrated pest management system that considered also other diseases, such as anthracnose (Colletotrichum gloeosporioides). Therefore, some tested active ingredients were not specific for controlling powdery mildew, such as copper oxychloride.

Contact multisite-activity fungicides (C) were alternated with systemic activity fungicides (S). Protection periods of 7 and 15 days were assigned to the multisite and to systemic fungicides, respectively. The treatments were established based on these periods. In the first flush (vegetative and floral), the following treatments were used: $\mathrm{T} 1, \mathrm{C}^{\mathrm{a}}+\mathrm{S}^{1 \mathrm{a}}+\mathrm{C}^{\mathrm{a}}+$ $\mathrm{S}^{2 \mathrm{a}} ; \mathrm{T} 2, \mathrm{~S}^{1 \mathrm{a}}+\mathrm{C}^{\mathrm{a}}+\mathrm{S}^{2 \mathrm{a}}+\mathrm{C}^{\mathrm{a}} ; \mathrm{T} 3, \mathrm{~S}^{1 \mathrm{a}}+\mathrm{C}^{\mathrm{a}}+\mathrm{C}^{\mathrm{a}}+\mathrm{S}^{2 \mathrm{a}} ; \mathrm{T} 4$, $\mathrm{C}^{\mathrm{a}}+\mathrm{S}^{1 \mathrm{a}}+\mathrm{S}^{2 \mathrm{a}}+\mathrm{C}^{\mathrm{a}}$; and $\mathrm{T} 5$, control; for which $\mathrm{S}^{1 \mathrm{a}}$ is azoxystrobin, $\mathrm{S}^{2 \mathrm{a}}$ is myclobutanil, $\mathrm{C}^{\mathrm{a}}$ is sulfur + copper oxychloride, and control is distilled water. In the second flush, only contact fungicides, with multisite activity, combined with sulfur, were applied, with the following treatments: $\mathrm{T} 1, \mathrm{Cu}+\mathrm{S}$ (copper oxychloride + sulfur); T2, Clo + S (chlorothalonil + sulfur); T3, $\mathrm{Ma}+\mathrm{S}$ (mancozeb + sulfur); $\mathrm{T} 4, \mathrm{Ca}+\mathrm{S}$ (captan +

Pesq. agropec. bras., Brasília, v.52, n.9, p.715-723, set. 2017

DOI: 10.1590/S0100-204X2017000900003 
sulfur); and T5, control (distilled water). In the third flush, the following treatments were applied: $\mathrm{T} 1$, $\mathrm{S}^{1 \mathrm{~b}}+\mathrm{C}^{\mathrm{b}}+\mathrm{S}^{2 \mathrm{~b}}+\mathrm{C}^{\mathrm{b}} ; \mathrm{T} 2, \mathrm{C}^{\mathrm{b}}+\mathrm{S}^{\mathrm{lb}}+\mathrm{C}^{\mathrm{b}}+\mathrm{S}^{2 \mathrm{~b}} ; \mathrm{T} 3, \mathrm{~S}^{1 \mathrm{~b}}+\mathrm{C}^{\mathrm{b}}+\mathrm{C}^{\mathrm{b}}+\mathrm{S}^{2 \mathrm{~b}}$; $\mathrm{T} 4, \mathrm{C}^{\mathrm{b}}+\mathrm{S}^{1 \mathrm{~b}}+\mathrm{S}^{2 \mathrm{~b}}+\mathrm{C}^{\mathrm{b}}$; and $\mathrm{T}$, control; in which $\mathrm{S}^{1 \mathrm{~b}}$ is cyprodinil + fludioxonil, $\mathrm{S}^{2 \mathrm{~b}}$ is quinoxyfen, and $\mathrm{C}^{\mathrm{b}}$ is chlorothalonil + sulfur.

The application of the chemical treatments was based on the floral phenology model (Guillén-Sánchez et al., 2003), which considers as the most susceptible stages those from swollen buds to fruit with diameters lower than $8 \mathrm{~mm}$. The fungicides were applied according to their commercial doses: azoxystrobin, $0.25 \mathrm{~g} \mathrm{~L}^{-1}$; myclobutanil, $0.08 \mathrm{~g} \mathrm{\textrm {L } ^ { - 1 }}$; cyprodinil+fludioxonil, $62.5+0.075 \mathrm{~g} \mathrm{~L}^{-1}$; quinoxyfen, $0.05 \mathrm{~mL} \mathrm{~L}^{-1}$; copper oxychloride, $2.5 \mathrm{~g} \mathrm{~L}^{-1}$; mancozeb, $0.8 \mathrm{~g} \mathrm{~L}^{-1}$; captan, $1.25 \mathrm{~g} \mathrm{~L}^{-1}$; chlorothalonil, $2.88 \mathrm{~g} \mathrm{~L}^{-1}$; and elemental sulfur, $1.35 \mathrm{mg} \mathrm{L}^{-1}$. The applications were done with a Swissmex agricultural handbarrow, with $500 \mathrm{~L}$ capacity and flow of $34.2 \mathrm{~L} \mathrm{~min}^{-1}$, at $20 \mathrm{bar}$, using 5.5-HP (4.1 kw) motor, at 3,600 rpm; with two $50 \mathrm{~m}$ hoses with aspersion handles.

A randomized complete block design was carried out with four replicates. In each one, five inflorescences and five vegetative shoots taken from a tree, with homogeneous growth flush, were randomly selected and labeled. A previous research had shown that there is no effect of the orientation of inflorescences and vegetative shoots on disease intensity (GuillénSánchez et al., 2003). Two logarithmic scales (Table 1), with 7 and 10 classes (k), were developed using the software Doslog v.1.0 for Windows, with the following grades, according to the leaf area affected by the disease: 0 , healthy tissue; and 6 , damaged area $\geq 40 \%$. For the inflorescence, the grades were: 0, healthy tissue; and 9, 90\% panicles completely infested with the fungus. Disease severity was estimated according to these grades, on a weekly basis, from the swollen buds detection until the fruit reached a diameter of 8-15 $\mathrm{mm}$, with the formula:

$$
\operatorname{Sev}_{\mathrm{i}}=\sum_{\mathrm{i}=1}^{\mathrm{k}} \mathrm{X}_{\mathrm{ki}} \times \mathrm{N}_{\mathrm{ki}} / \mathrm{Ni},
$$

in which: $\operatorname{Sev}_{\mathrm{i}}$ is the severity at time $\mathrm{i} ; \mathrm{X}_{\mathrm{ki}}$ is the damage level $\mathrm{k}$ at time $\mathrm{i} ; \mathrm{N}_{\mathrm{ki}}$ represents the inflorescences with damage level $\mathrm{k}$ at time $\mathrm{I} ; \mathrm{N}_{\mathrm{i}}$ are inflorescences evaluated at time $\mathrm{i}$.

The temporal analysis of the disease progress was made by adjusting growth curves with the models monomolecular, logistic, and Gompertz, taking into account the coefficients of determination $\left(\mathrm{R}^{2}\right)$ and the quality of the fit, standardized with the Weibull model $\left(b^{-1}\right)$. In order to compare the effect of the factors on the disease, the final severity $\left(\mathrm{Y}_{\mathrm{f}}\right)$ and the area under the disease progress curve (AUDPC) were calculated for each treatment, by integrating the Trapezoidal method (Campbell \& Madden, 1990; Campbell \& Benson, 1994).

The analysis of variance (Proc GLM) and the comparison of the mean (LSD test with reliability of 95\%) were carried out in SAS v.9.1.3 (SAS Institute Inc, Cary, NC, USA) statistical software.

Temperature, precipitation, relative humidity, dew point, and wind direction and speed were recorded every two hours, with a Vantage Pro2 Weather Station (Davis Instruments Hayward California, USA), equipped with a Wheatherlink for Windows, v.5.9.0 software. The station was configured with a laptop, and data were exported to Microsoft Excel spreadsheet for processing.

In order to estimate the density of $O$. mangiferae conidia in the air, volumetric spore traps were designed, constructed, and installed in the center of the experimental area, at $1.5 \mathrm{~m}$ above ground level. The air suction was performed with a blower motor for industrial use, with $12 \mathrm{~V}$, and a volumetric capacity of 2.3-3.5 $\mathrm{L} \mathrm{min}^{-1}$. Inside the trap, the spores were attached onto an adhesive tape placed around a rotating plastic disk, with a digital mechanism scheduled for seven days. Each tape had $1.5 \times 39.5 \mathrm{~cm}$, taken from rolls of transparent self-adhesive polypropylene (Contac).

Table 1. Logarithmic scale used for the evaluation of powdery mildew (Oidium mangiferae) on inflorescences and leaves of mango (Mangifera indica), in the subhumid tropics of Guerrero, Mexico, during flowering and vegetative growth of the plants.

\begin{tabular}{lccc}
\hline $\begin{array}{l}\text { Classe } \\
(\mathrm{k})\end{array}$ & \multicolumn{2}{c}{ Severity (\%) } & $\begin{array}{c}\text { Diseased } \\
\text { flowering axes }\end{array}$ \\
\cline { 2 - 3 } & Leaves & Inflorescences & 0 \\
1 & 0 & 0 & 9 \\
2 & $>0-2$ & $>0-1.6$ & 19 \\
3 & $>2-4$ & $>1.6-3.5$ & 39 \\
4 & $>4-10$ & $>3.5-7.4$ & 79 \\
5 & $>10-21$ & $>7.4-15$ & 148 \\
6 & $>21-40$ & $>15-28$ & 243 \\
7 & $>40$ & $>28-46$ & 347 \\
8 & - & $>46-65$ & 425 \\
9 & - & $>65-80$ & All \\
\hline
\end{tabular}


The tapes were tightly attached to a strip sheet of a hygrothermograph (as a template), around a plastic disk. This helped to differentiate individual days and hours of spore trapping. The tapes were removed weekly, and each $39.5-\mathrm{mm}$ section of the template corresponded to a trapping interval of 24 hours. They were examined under a compound microscope, at $40 \mathrm{X}$, for daily and weekly quantification of the spore density in the air.

Pearson correlation coefficients (r) were calculated between disease intensity and conidia density, and climatic conditions of temperature, relative humidity, speed and direction of the wind, precipitation, and dew point.

\section{Results and Discussion}

Flowering (F11, F12, and F13) and vegetative flushes (Veg1, Veg2, and Veg3) were registered and, in the experimental site, with subhumid tropic climatic conditions, they occurred in the periods shown in Figure 1, which depicts the severity of the disease in the field accordingly to the scale used, and allowed of the temporal development estimation of the epidemics. The first symptoms of the disease were observed, on average, 30 days after the appearance of the swollen buds. The most susceptible phenological stages were: full flowering, with $30 \%$ severity fruit set $(3-5 \mathrm{~mm}$ diameter); and fruit with $8-15 \mathrm{~mm}$, with $35 \%$ severity.
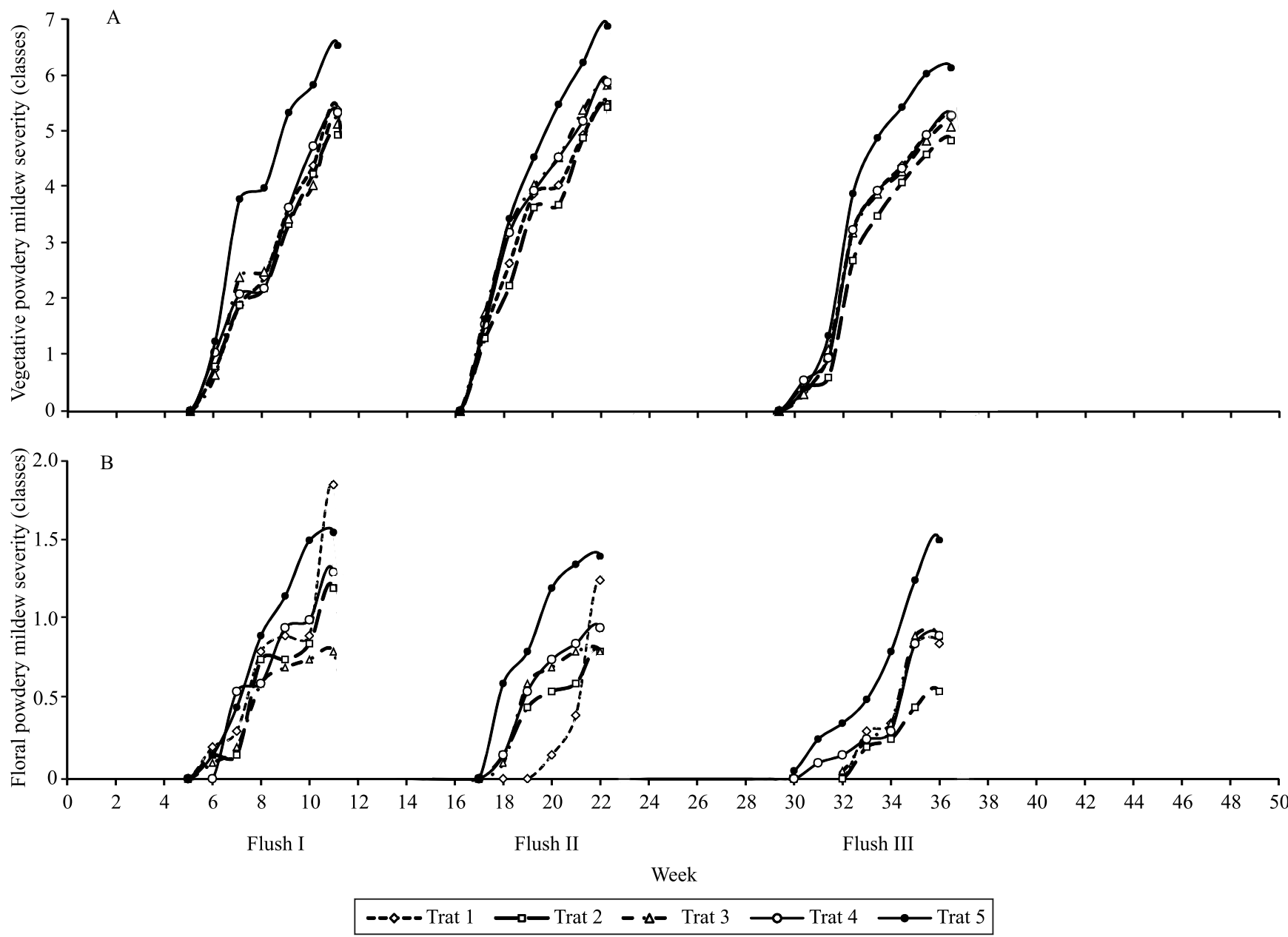

Figure 1. Temporal progress curves for disease severity during the vegetative (A) and flowering (B) stages of mango with epidemics of Oidium mangiferae during three growth flushes, according to five chemical treatments, in a commercial mango orchard (Mangifera indica 'Manila') in Las Tunas. $\mathrm{C}^{\mathrm{a}}$, sulfur + copper oxychloride; $\mathrm{S}^{1 \mathrm{a}}$, azoxystrobin; $\mathrm{S}^{2 a}$, myclobutanil; $\mathrm{C}^{\mathrm{b}}$, chlorothalonil + sulfur; $\mathrm{S}^{1 \mathrm{~b}}$, cyprodinil + fludioxonil; $\mathrm{S}^{2 \mathrm{~b}}$, quinoxyfen; $\mathrm{Cu}+\mathrm{S}$, copper oxychloride + sulfur; chlo $+\mathrm{S}$, chlorothalonil + sulfur; $\mathrm{Ma}+\mathrm{S}$, mancozeb + sulfur; and $\mathrm{Ca}+\mathrm{S}$, captan + sulfur. 
Joubert (1991), Schoeman et al. (1995), and GuillénSánchez et al. (2003) reported similar results. The maximum severity in inflorescences $\left(\mathrm{F} 11, \mathrm{Y}_{\mathrm{f}}=6.55 ; \mathrm{F} 12\right.$ $\mathrm{Y}_{\mathrm{f}}=6.90$; and $\left.\mathrm{Fl3} \mathrm{Y}_{\mathrm{f}}=6.15\right)$ and in vegetative shoots $\left(\mathrm{Veg} 2, \mathrm{Y}_{\mathrm{f}}=1.80\right.$; and $\left.\mathrm{Veg} 3, \mathrm{Y}_{\mathrm{f}}=1.65\right)$ was recorded 40 days after initial symptoms (Tables 2 and 3).

According to Singh (2000), warm humid weather, low-night temperatures, and high-wind velocity favor disease spread and development. These climatic conditions are common in the subhumid tropic region evaluated, and explain why the disease was found during all three growth flushes. The climatic conditions impacted the disease severity, with correlation coefficients ranging from 0.82 to 0.93

Table 2. Effect of different fungicide combinations and of their application order on the epidemiological variables and on severity of powdery mildew (Oidium mangiferae), in the flowering stage of mango (Mangifera indica), in the subhumid tropic of Guerrero, Mexico ${ }^{(1)}$.

\begin{tabular}{|c|c|c|c|c|c|}
\hline \multirow{2}{*}{$\begin{array}{l}\text { Treat- } \\
\text { ment }\end{array}$} & \multirow{2}{*}{$\begin{array}{c}\text { Order of } \\
\text { application }^{(2)}\end{array}$} & \multirow{2}{*}{$\begin{array}{c}\text { Weibull } \\
\left(\mathrm{R}^{2}\right)\end{array}$} & \multicolumn{3}{|c|}{ Epidemiological parameters $^{(3)}$} \\
\hline & & & $\mathrm{Y}_{\mathrm{f}}$ & $\left(b^{-1}\right)$ & AUDPC \\
\hline & \multicolumn{5}{|c|}{ Flowering flush 1} \\
\hline $\mathrm{T} 1$ & $\mathrm{~S}^{\mathrm{la}}+\mathrm{C}^{\mathrm{a}}+\mathrm{S}^{2 \mathrm{a}}+\mathrm{C}^{\mathrm{a}}$ & 0.99 & $4.95 \mathrm{c}$ & $0.06 \mathrm{a}$ & $145.75 \mathrm{c}$ \\
\hline $\mathrm{T} 2$ & $\mathrm{C}^{\mathrm{a}}+\mathrm{S}^{\mathrm{la}}+\mathrm{C}^{\mathrm{a}}+\mathrm{S}^{2 \mathrm{a}}$ & 0.97 & $5.40 \mathrm{~b}$ & $0.17 \mathrm{a}$ & $151.00 \mathrm{bc}$ \\
\hline $\mathrm{T} 3$ & $\mathrm{~S}^{\mathrm{la}}+\mathrm{C}^{\mathrm{a}}+\mathrm{C}^{\mathrm{a}}+\mathrm{S}^{2 \mathrm{a}}$ & 0.98 & $5.15 b c$ & $0.18 \mathrm{a}$ & $154.25 \mathrm{bc}$ \\
\hline $\mathrm{T} 4$ & $\mathrm{C}^{\mathrm{a}}+\mathrm{S}^{\mathrm{la}}+\mathrm{S}^{2 \mathrm{a}}+\mathrm{C}^{\mathrm{a}}$ & 0.98 & $5.35 \mathrm{~b}$ & $0.18 \mathrm{a}$ & $159.00 \mathrm{~b}$ \\
\hline \multirow[t]{2}{*}{$\mathrm{T} 5$} & Control & 0.99 & $6.55 \mathrm{a}$ & $0.21 \mathrm{a}$ & $229.00 \mathrm{a}$ \\
\hline & \multicolumn{5}{|c|}{ Flowering flush 2} \\
\hline $\mathrm{T} 1$ & $\mathrm{Cu}+\mathrm{S}$ & 0.99 & $5.50 \mathrm{c}$ & $0.33 \mathrm{a}$ & $190.25 \mathrm{c}$ \\
\hline $\mathrm{T} 2$ & $\mathrm{Chlo}+\mathrm{S}$ & 0.98 & $5.45 \mathrm{c}$ & $0.44 \mathrm{a}$ & $178.75 d$ \\
\hline $\mathrm{T} 3$ & $\mathrm{Ma}+\mathrm{S}$ & 0.97 & $5.85 \mathrm{~b}$ & $0.22 \mathrm{a}$ & $211.00 \mathrm{~b}$ \\
\hline $\mathrm{T} 4$ & $\mathrm{Ca}+\mathrm{S}$ & 0.99 & $5.90 \mathrm{~b}$ & $0.23 \mathrm{a}$ & $206.25 b$ \\
\hline \multirow[t]{2}{*}{ T5 } & Control & 0.99 & $6.90 \mathrm{a}$ & $0.39 \mathrm{a}$ & $240.25 \mathrm{a}$ \\
\hline & \multicolumn{5}{|c|}{ Flowering flush 1} \\
\hline $\mathrm{T} 1$ & $\mathrm{~S}^{1 \mathrm{~b}}+\mathrm{C}^{\mathrm{b}}+\mathrm{S}^{2 \mathrm{~b}}+\mathrm{C}^{\mathrm{b}}$ & 0.95 & $4.85 \mathrm{~d}$ & $0.23 \mathrm{a}$ & $181.50 \mathrm{c}$ \\
\hline $\mathrm{T} 2$ & $\mathrm{C}^{\mathrm{b}}+\mathrm{S}^{1 \mathrm{~b}}+\mathrm{C}^{\mathrm{b}}+\mathrm{S}^{2 \mathrm{~b}}$ & 0.96 & $5.25 \mathrm{bc}$ & $0.22 \mathrm{a}$ & $203.50 \mathrm{~b}$ \\
\hline $\mathrm{T} 3$ & $\mathrm{~S}^{1 \mathrm{~b}}+\mathrm{C}^{\mathrm{b}}+\mathrm{C}^{\mathrm{b}}+\mathrm{S}^{2 \mathrm{~b}}$ & 0.96 & $5.10 \mathrm{c}$ & $0.27 \mathrm{a}$ & $200.50 \mathrm{~b}$ \\
\hline $\mathrm{T} 4$ & $\mathrm{C}^{\mathrm{b}}+\mathrm{S}^{1 \mathrm{~b}}+\mathrm{S}^{2 \mathrm{~b}}+\mathrm{C}^{\mathrm{b}}$ & 0.97 & $5.30 \mathrm{~b}$ & $0.40 \mathrm{a}$ & $203.75 b$ \\
\hline $\mathrm{T} 5$ & Control & 0.99 & $6.15 \mathrm{a}$ & $0.36 \mathrm{a}$ & $249.25 \mathrm{a}$ \\
\hline
\end{tabular}

${ }^{(1)}$ Means followed by equal letters do not differ, by LSD test, at $5 \%$ probability. ${ }^{(2)} \mathrm{S}^{1 a}$, azoxystrobin; $\mathrm{S}^{2 a}$, myclobutanil; $\mathrm{C}^{\mathrm{a}}$, sulfur + copper oxychloride; $\mathrm{Cu}+\mathrm{S}$, copper oxychloride + sulfur; $\mathrm{Chlo}+\mathrm{S}$, chlorothalonil + sulfur; $\mathrm{Ma}+\mathrm{S}$, mancozeb + sulfur; $\mathrm{Ca}+\mathrm{S}$, captan + sulfur; $\mathrm{S}^{\mathrm{lb}}$, cyprodinil + fludioxonil; $\mathrm{S}^{2 \mathrm{~b}}$, quinoxyfen; and $\mathrm{C}^{\mathrm{b}}$, chlorothalonil + sulfur. ${ }^{(3)} \mathrm{Y}_{\mathrm{f}}$, final incidence; $\mathrm{b}^{-1}$, apparent infection rate; and AUDPC, area under the disease progress curve.
(Table 4). Epidemic relevance of the disease in foliage is significant, since it provides a source of inocula that can infect the inflorescences, both in the same production cycle and in the following growing seasons (Akhtar \& Alam, 2002; Guillén-Sánchez et al., 2003). However, future studies are needed to estimate their impact on tree vigor.

The treatment with the best result in the inflorecences was $\mathrm{T} 1\left[\mathrm{~S}^{\mathrm{a}}+\mathrm{C}^{\mathrm{a}}+\mathrm{S}^{2 \mathrm{a}}+\mathrm{C}^{\mathrm{a}}=\right.$ azoxystrobin, sulfur + copper oxychloride + myclobutanil + (sulfur + copper oxychloride)], that showed $\mathrm{Y}_{\mathrm{f}}$ lower than 4.95 and AUDPC of 145.75, in the first flowering flush. In vegetative shoots, however, the best results were obtained with $\mathrm{T} 3\left(\mathrm{~S}^{\mathrm{a}}+\mathrm{C}^{\mathrm{a}}+\mathrm{C}^{\mathrm{a}}+\mathrm{S}^{2 \mathrm{a}}\right)$, that showed $\mathrm{Y}_{\mathrm{f}}=1.00$, and $\mathrm{AUDPC}=26.5$.

In the second growth flush, when systemic fungicides were not used, the best combination of ingredients were chlorothalonil + sulfur, with $\mathrm{AUDPC}=178.75$ in the flowering; and copper oxychloride + sulfur, with AUDPC $=11.75$ in the vegetative shoots. This last result suggests a synergistic effect of the combination with sulfur.

In the third and final growth flush, the best treatment was $\mathrm{T} 1\left[\mathrm{~S}^{1 \mathrm{~b}}+\mathrm{C}^{\mathrm{b}}+\mathrm{S}^{2 \mathrm{~b}}+\mathrm{C}^{\mathrm{b}}=\right.$ quinoxyfen + (chlorothalonil + sulfur $)+($ cyprodinil + fludioxonil $)+$ (chlorothalonil + sulfur)], both for inflorescences - that showed $\mathrm{Y}_{\mathrm{f}}=4.85$, and AUDPC $=181.50$ - and foliage, with $\mathrm{Y}_{\mathrm{f}}=0.60$, and $\mathrm{AUDPC}=11.50$ (Tables 2 and 3). The control treatment recorded the highest intensity of disease in all flower and vegetative stages evaluated.

The Weibull model described well (Madden et al., 1981; Sinha \& Varma, 2004) most of the registered epidemics, with $\mathrm{R}^{2}$ higher than 0.85 (Figure 1). However, there were differences in apparent infection rates, due to the treatments, only in the vegetative flushes 1 and 3 (Table 3). There were no expressive differences of treatment effects on the development of the disease in vegetative or flowering flushes (Tables 2 and 3). Fungicides from different chemical groups and modes of action, or with multisite activity, are commonly reported as controlling powdery mildew in mango (Hollomon et al., 1997; Reuveni et al., 1998; Wicks \& Hitch, 2002; Guillén-Sánchez et al., 2004; Nelson, 2008). These reports were confirmed in the present study, where azoxystrobin, myclobutanil, and copper oxychloride + sulfur were the most effective fungicides. 
However, the present study, not only evaluated specific authorized fungicides (MRL, 2010; Sagarpa, 2010) for powdery mildew in mango, but also their alternated use and the sprayed order, aiming at the preservation of their effectiveness with a rational phytosanitary approach (Halleen \& Holz, 2001). Overall, the best strategy was to initiate chemical control using a systemic fungicide, followed by a contact one with multisite activity. In addition, the application time should consider the availability of susceptible tissues (full flowering, fruit set of 3-5 mm, and fruit with $8-15 \mathrm{~mm}$ diameter), regardless of the number and intensity of the growth flushes (Schoeman et al., 1995; Halleen \& Holz, 2001). This strategy should be combined with cultural practices to reduce environmental humidity in the orchard, such as ventilation pruning, elimination of inoculum sources, avoiding excessive irrigation, and improving drainage and the timely control of weeds (Saifullah et al., 2007).
Moreover, periodical foliar phosphate fertilization (Reuveni \& Reuveni, 2002) can also help to improve the control of the disease. These practices may preserve long-term effectiveness of systemic molecules, thus limiting the risk of generating resistance (Halleen \& Holz, 2001; FRAC, 2012).

The periodic occurrence of cold winds $\left(\leq 20^{\circ} \mathrm{C}\right)$ in subhumid tropical regions near the sea, as occurred in this study, has an important impact on the promotion of the floral initiation processes (Pérez \& Puche, 2003), but it can also increase the susceptibility of mango plants to powdery mildew, as observed in Técpan de Galeana (subhumid tropic), Guerrero. In areas with more than one epidemic (more than one growth flush) per cycle, the chemical control should be carried out more often. Therefore, it is important to alternate the active ingredients, with different combinations and order of application (FRAC, 2012), as Tahir et al.

Table 3. Effect of different fungicide combinations, and of their application order, on the epidemiological variables and on severity of powdery mildew (Oidium mangiferae), in the vegetative stages of mango (Mangifera indica), in the subhumid tropic of Guerrero, Mexico ${ }^{(1)}$.

\begin{tabular}{|c|c|c|c|c|c|c|c|}
\hline \multirow[t]{2}{*}{ Treatment } & \multirow{2}{*}{$\begin{array}{c}\text { Order of } \\
\text { application }^{(2)}\end{array}$} & \multirow[t]{2}{*}{ Weibull $\left(\mathrm{R}^{2}\right)$} & \multicolumn{5}{|c|}{ Epidemiological parameters ${ }^{(3)}$} \\
\hline & & & \multicolumn{2}{|c|}{$Y_{\mathrm{f}}$} & \multicolumn{2}{|c|}{$\left(b^{-1}\right)$} & AUDPC \\
\hline & \multicolumn{7}{|c|}{ Vegetative flush 1} \\
\hline $\mathrm{T} 1$ & $\mathrm{~S}^{1 \mathrm{a}}+\mathrm{C}^{\mathrm{a}}+\mathrm{S}^{2 \mathrm{a}}+\mathrm{C}^{\mathrm{a}}$ & 0.89 & $1.35 \mathrm{~cd}$ & $0.08 \mathrm{ab}$ & $31.75 b c$ & 0.89 & $1.35 \mathrm{~cd}$ \\
\hline $\mathrm{T} 2$ & $\mathrm{C}^{\mathrm{a}}+\mathrm{S}^{\mathrm{la}}+\mathrm{C}^{\mathrm{a}}+\mathrm{S}^{2 \mathrm{a}}$ & 0.85 & $1.85 \mathrm{a}$ & $0.11 \mathrm{a}$ & $40.25 \mathrm{ab}$ & 0.85 & $1.85 \mathrm{a}$ \\
\hline T3 & $\mathrm{S}^{1 \mathrm{a}}+\mathrm{C}^{\mathrm{a}}+\mathrm{C}^{\mathrm{a}}+\mathrm{S}^{2 \mathrm{a}}$ & 0.93 & $1.00 \mathrm{~d}$ & $0.08 \mathrm{ab}$ & $26.50 \mathrm{c}$ & 0.93 & $1.00 \mathrm{~d}$ \\
\hline $\mathrm{T} 4$ & $\mathrm{C}^{\mathrm{a}}+\mathrm{S}^{\mathrm{la}}+\mathrm{S}^{2 \mathrm{a}}+\mathrm{C}^{\mathrm{a}}$ & 0.93 & $1.45 b c$ & $0.07 \mathrm{ab}$ & $36.75 \mathrm{abc}$ & 0.93 & $1.45 \mathrm{bc}$ \\
\hline \multirow[t]{2}{*}{$\mathrm{T} 5$} & Control & 0.93 & $1.75 \mathrm{ab}$ & $0.05 b$ & $47.50 \mathrm{a}$ & 0.93 & $1.75 \mathrm{ab}$ \\
\hline & \multicolumn{7}{|c|}{ Vegetative flush 2} \\
\hline $\mathrm{T} 1$ & $\mathrm{Cu}+\mathrm{S}$ & 0.99 & $1.25 b$ & $0.09 \mathrm{a}$ & $11.75 \mathrm{c}$ & 0.99 & $1.25 \mathrm{~b}$ \\
\hline $\mathrm{T} 2$ & Chlo $+\mathrm{S}$ & 0.95 & $1.05 \mathrm{~b}$ & $0.10 \mathrm{a}$ & $20.25 b$ & 0.95 & $1.05 \mathrm{~b}$ \\
\hline T3 & $\mathrm{Ma}+\mathrm{S}$ & 0.90 & $1.10 \mathrm{~b}$ & $0.05 \mathrm{a}$ & $24.50 \mathrm{~b}$ & 0.90 & $1.10 \mathrm{~b}$ \\
\hline $\mathrm{T} 4$ & $\mathrm{Ca}+\mathrm{S}$ & 0.98 & $1.10 \mathrm{~b}$ & $0.07 \mathrm{a}$ & $27.00 \mathrm{~b}$ & 0.98 & $1.10 \mathrm{~b}$ \\
\hline \multirow[t]{2}{*}{$\mathrm{T} 5$} & Control & 0.92 & $1.80 \mathrm{~b}$ & $0.05 \mathrm{a}$ & $44.50 \mathrm{a}$ & 0.92 & $1.80 \mathrm{~b}$ \\
\hline & \multicolumn{7}{|c|}{ Vegetative flush 1} \\
\hline $\mathrm{T} 1$ & $\mathrm{~S}^{1 \mathrm{~b}}+\mathrm{C}^{\mathrm{b}}+\mathrm{S}^{2 \mathrm{~b}}+\mathrm{C}^{\mathrm{b}}$ & 0.96 & $0.60 \mathrm{c}$ & $0.08 \mathrm{c}$ & $11.50 \mathrm{c}$ & 0.96 & $0.60 \mathrm{c}$ \\
\hline $\mathrm{T} 2$ & $\mathrm{C}^{\mathrm{b}}+\mathrm{S}^{1 \mathrm{~b}}+\mathrm{C}^{\mathrm{b}}+\mathrm{S}^{2 \mathrm{~b}}$ & 0.95 & $1.00 \mathrm{~b}$ & $0.08 \mathrm{bc}$ & $18.50 \mathrm{bc}$ & 0.95 & $1.00 \mathrm{~b}$ \\
\hline $\mathrm{T} 3$ & $\mathrm{~S}^{1 \mathrm{~b}}+\mathrm{C}^{\mathrm{b}}+\mathrm{C}^{\mathrm{b}}+\mathrm{S}^{2 \mathrm{~b}}$ & 0.94 & $1.05 \mathrm{~b}$ & $0.10 \mathrm{abc}$ & $19.25 b c$ & 0.94 & $1.05 \mathrm{~b}$ \\
\hline $\mathrm{T} 4$ & $\mathrm{C}^{\mathrm{b}}+\mathrm{S}^{1 \mathrm{~b}}+\mathrm{S}^{2 \mathrm{~b}}+\mathrm{C}^{\mathrm{b}}$ & 0.93 & $1.05 \mathrm{~b}$ & $0.14 \mathrm{ab}$ & $20.25 b$ & 0.93 & $1.05 \mathrm{~b}$ \\
\hline $\mathrm{T} 5$ & Control & 0.97 & $1.65 \mathrm{a}$ & $0.14 \mathrm{a}$ & $38.75 \mathrm{a}$ & 0.97 & $1.65 \mathrm{a}$ \\
\hline
\end{tabular}

${ }^{(1)}$ Means followed by equal letters do not differ, by LSD test, at $5 \%$ probability. ${ }^{(2)} \mathrm{S}^{1 \mathrm{a}}$, azoxystrobin; $\mathrm{S}^{2 \mathrm{a}}$, myclobutanil; $\mathrm{C}^{\mathrm{a}}$, sulfur + copper oxychloride; $\mathrm{Cu}+\mathrm{S}$, copper oxychloride + sulfur; Chlo $+\mathrm{S}$, chlorothalonil + sulfur; $\mathrm{Ma}+\mathrm{S}$, mancozeb + sulfur; $\mathrm{Ca}+\mathrm{S}$, captan + sulfur; $\mathrm{S}^{1 \mathrm{~b}}$, cyprodinil + fludioxonil; $\mathrm{S}^{2 \mathrm{~b}}$, quinoxyfen; and $\mathrm{C}^{\mathrm{b}}$, chlorothalonil + sulfur. ${ }^{(3)} \mathrm{Y}_{\mathrm{f}}$, final incidence; $\mathrm{b}^{-1}$, apparent infection rate; and AUDPC, area under the disease progress curve. 
Table 4. Pearson correlation coefficient of powdery mildew (Oidium mangiferae) spore density in the air, with climatic variables and with disease severity in mango (Mangifera indica).

\begin{tabular}{lc}
\hline Range & $\begin{array}{c}\text { Correlation of spore density with environmental } \\
\text { conditions and with disease severity }\end{array}$ \\
\hline$\geq 30^{\circ} \mathrm{C}$ & 0.95 \\
\hline $60-89 \%$ & Daytime temperature ${ }^{(1)}$ \\
$\geq 90 \%$ & 0.65 \\
\hline & 0.86 \\
$10-14^{\circ} \mathrm{C}$ & Dew point \\
$15-19^{\circ} \mathrm{C}$ & 0.83 \\
& 0.68 \\
1 & 0.91 \\
3 & 0.94 \\
& 0.90 \\
1 & Disease severity in flowering flush \\
2 & Disease severity in vegetative flush \\
3 & 0.93 \\
\hline
\end{tabular}

(1) Night temperature oscillated around $15 \pm 3^{\circ} \mathrm{C}$.
(2009) reported for O. mangiferae, and Halleen \& Holz (2001) for Uncinula necator on grapevines.

In the present study, the severity in flowering and vegetative flushes were associated with temperatures higher than $30^{\circ} \mathrm{C}(\mathrm{r}=0.92$ and 0.94 , respectively), relative humidity $\geq 90 \%$ ( $\mathrm{r}=0.80$ and 0.93 ), and density of air sporulation ( $\mathrm{r}=0.88$ and 0.96$)$. In addition, spore density was correlated with temperatures between 20 and $26.9^{\circ} \mathrm{C}(\mathrm{r}=0.65)$, relative humidity between 60 and $89.9 \%(\mathrm{r}=0.65)$, dew point between 15 and $19.9^{\circ} \mathrm{C}$ $(\mathrm{r}=0.63)$, and wind speed between $1-1.9 \mathrm{~km} \mathrm{~h}^{-1}(\mathrm{r}=0.70)$ (with $\mathrm{WN}$ direction, $\mathrm{r}=0.88$ ).

Flowering and vegetative severity of the disease were correlated with temperature higher than $30^{\circ} \mathrm{C}$ and relative humidity higher than $90 \%$. Therefore, these parameters were considered determinant for the development of the disease. Inocula were present throughout the studied period (Figure 2). Therefore, the severity will depend only on the proportion of susceptible tissues and on favorable environmental conditions. Singh (2000) reported that warm humid
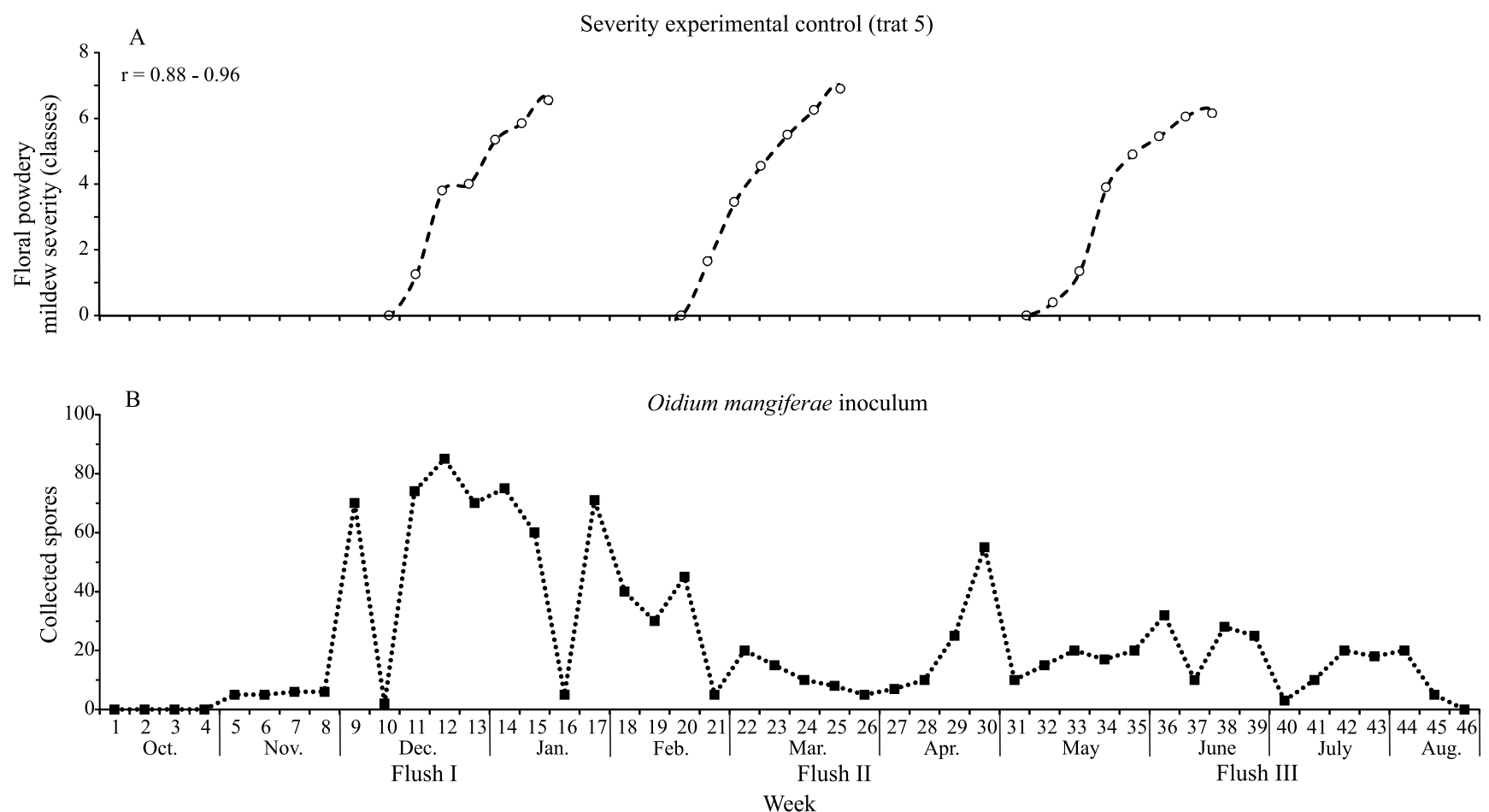

Figure 2. Oidium mangiferae spores monitoring (A), and their relationship with disease severity on inflorescences (B), during three flowering flushes, in a commercial 'Manila' mango orchard (Mangifera indica), in Las Tunas. 
weather (64-72\%), low-night temperatures, and highwind velocity favor the spread of powdery mildew. Moreover, it is reported that maximum sporulation occurs between 20 and $26.9^{\circ} \mathrm{C}$, with relative humidity higher than $80 \%$, and dew point between $20-24.9^{\circ} \mathrm{C}$ (Makowski, 1993; Akhtar \& Alam, 2000; Halleen \& Holz, 2001; Sinha et al., 2001). It has also been documented that temperatures above $35^{\circ} \mathrm{C}$, humidity between 50 and $70 \%$, and wind exceeding $1.0 \mathrm{~km} \mathrm{~h}^{-1}$ favor conidial dispersal (Schoeman et al., 1995; Akhtar \& Alam, 2000; Singh, 2000).

\section{Conclusions}

1. The rotation of molecules, particularly starting with one with systemic activity, followed by a contact fungicide with multisite activity, provides an efficient tool to combat the severity of powdery mildew (Oidium mangiferae) in mango, and to prevent the fungal resistance to fungicides.

2. Full flowering, initial berthing of fruit, and fruit with $8-15 \mathrm{~mm}$ diameter are critical stages of infection.

3. Low-night temperatures (below $20^{\circ} \mathrm{C}$ ) and diurnal temperatures higher than $30^{\circ} \mathrm{C}$, combined with humidity over $90 \%$, are highly related to the severity of the disease.

\section{Acknowledgments}

To Colegio de Postgraduados, Mexico and SagarpaConacyt Project No. 48595, for financial support.

\section{References}

AKHTAR, K.P.; ALAM, S.S. Assessment keys for some important diseases of mango. Pakistan Journal of Biological Sciences, v.5, p.246-250, 2002. DOI: 10.3923/pjbs.2002.246.250.

AKHTAR, K.P.; ALAM, S.S. Powdery mildew of mango: a review. Pakistan Journal of Biological Sciences, v.3, p.11191122, 2000. DOI: 10.3923/pjbs.2000.1119.1122.

CAMPBELL, C.L.; BENSON, D.M. Spatial aspects of the development of root disease epidemics. In: CAMPBELL, C.L.; BENSON, D.M. (Ed.). Epidemiology and Management of Root Diseases. Berlin: Springer-Verlag, 1994. p.195-243. DOI: 10.1007/978-3-642-85063-9_7.

CAMPBELL, C.L.; MADDEN, L.V. Introduction to plant disease epidemiology. New York: J. Wiley, 1990.

FAO. Food and Agriculture Organization of the United Nations. Faostat. 2016. Available at: <http://faostat3.fao.org/browse/Q/*/ E>. Accessed on: Oct. 242016.
FÉLIX-GASTÉLUM， R.; HERRERA-RODRÍGUEZ， G.; MARTÍNEZ-VALENZUELA， C.; LONGORIA-ESPINOZA, R.M.; MALDONADO-MENDOZA, I.E.; QUIROZ-FIGUEROA, F.R.; MARTÍNEZ-ÁLVAREZ， J.C.; GARCÍA-PÉREZ， L.M.; ESPINOSA-MATÍAS, S. First report of powdery mildew (Pseudoidium anacardii) of mango trees in Sinaloa, Mexico. Plant Disease, v.97, p.994, 2013. DOI: 10.1094/PDIS-11-12-1014-PDN.

FRAC. Fungicide Resistance Action Committee. 2012. Available at: <http://www.frac.info>. Accessed on: June 212016.

GUILLÉN-SÁNCHEZ， D.; TÉLIZ-ORTÍZ， D.; MORAAGUILERA, A.; NIETO-ANGEL, D.; CÁRDENAS-SORIANO, E.; SIEBE-GRABACH, C.; VILLANUEVA-JIMÉNEZ, J.A. La severidad de la cenicilla (Oidium mangiferae Berthet) del mango (Mangifera indica L.) y su relación con las emisiones de ceniza de una central termoeléctrica. Revista Mexicana de Fitopatología, v.22, p.90-99, 2004.

GUILLÉN-SÁNCHEZ， D.; TÉLIZ-ORTÍZ， D; MORAAGUILERA, G.; MORA-AGUILERA, A.; SÁNCHEZ-GARCÍA, P.; GONZÁLEZ-HERNÁNDEZ, V. Desarrollo temporal de epidemias de cenicilla (Oidium mangiferae Berthet) en huertos de mango (Mangifera indica L.) en Michoacán, México. Revista Mexicana de Fitopatología, v.21, p.181-188, 2003.

HALLEEN, F.; HOLZ, G. An overview of the biology, epidemiology and control of Uncinula necator (powdery mildew) on grapevine, with reference to South Africa. South African Journal for Enology and Viticulture, v.22, p.111-121, 2001. DOI: $10.21548 / 22-2-2205$

HOLLOMON, D.W.; WHEELER, I.; DIXON, K.; LONGHURST, C.; SKYLAKAKIS, G. Defining de resistance risk of the new powdery mildew fungicide quinoxyfen. Pesticide Science, v.51, p.347-351, 1997. DOI: 10.1002/(SICI)10969063(199711)51:3<347::AID-PS651>3.0.CO;2-3.

JOUBERT, M.H. Implications of epidemiological studies on strategies for control of powdery mildew and anthracnose. Yearbook South African Mango Growers' Association, v.11, p.26-28, 1991.

MADDEN, L.V.; PENNYPACKER, S.P.; KINGSOLVER, C.H. A comparison of crop loss models. Journal of Phytopathology, v.101, p.196-201, 1981. DOI: 10.1111/j.1439-0434.1981.tb03340.x.

MAKOWSKI, R.M.D. Effect of inoculum concentration, temperature, dew period, and plant growth stage on disease of round-leaved mallow and velvetleaf by Colletotrichum gloeosporioides f. sp. malvae. Phytopathology, v.83, p.12291234, 1993. DOI: 10.1094/Phyto-83-1229.

MARGOT, P.; HUGGENBERGER, F.; AMREIN, J.; WEISS, B. CGA 279202: a new broad-spectrum strobilurin fungicide. In: BRIGHTON CROP PROTECTION CONFERENCE, 1998, Brighton. Pests and diseases: proceedings. Farnham: British Crop Protection Council, 1998. v.2, p.375-382.

MORA AGUILERA, A.; TÉLIZ ORTIZ, D.; SÃO JOSÉ, A.R. (Ed.). El mango: manejo y comercialización. Texcoco: Colegio de Postgraduados; Vitória da Conquista: Universidade Estadual do Sudoeste da Bahia, 2002. 
MRL. Maximum Residue Limits Database. 2010. Available at: $<$ http://www.fas.usda.gov/data/mexico-maximum-residue-limitspesticides-agricultural-use $>$. Accessed on: June 212016.

NASIR, M.; MUGHAL, S.M.; MUKHTAR, T.; AWAN, M.Z. Powdery mildew of mango: a review of ecology, biology, epidemiology and management. Crop Protection, v.64, p.19-26, 2014. DOI: 10.1016/j.cropro.2014.06.003.

NELSON, S.C. Mango powdery mildew. [Honolulu]: University of Hawaii, 2008. 6p. (Plant Disease; PD-46). Available at: <http:// hdl.handle.net/10125/12411>. Accessed on: June 212016.

PÉREZ, A.M.; PUCHE, M. La temperatura como herramienta de predicción agroclimatológica aplicada a la producción de frutales. CENIAP HOY, n.3, 2003. Available at: <http://sian.inia.gob.ve/ repositorio/revistas_tec/ceniaphoy/articulos/n3/texto/mazkue. html>. Accessed on: June 212016.

REUVENI, M.; HARPAZ, M.; REUVENI, R. Integrated control of powdery mildew on field-grown mango trees by foliar sprays of mono-potassium phosphate fertilizer, sterol inhibitor fungicides and the strobilurin kresoxym-methyl. European Journal of Plant Pathology, v.104, p.853-860, 1998. DOI: 10.1023/A:1008624106269.

REUVENI, M.; REUVENI, R. Mono-potassium phosphate fertilizer (peak) - a component in integrated control of powdery mildews in fruit trees and grapevines. Acta Horticulturae, v.594, p.619-625, 2002. DOI: 10.17660/ActaHortic.2002.594.83.

SAGARPA. Secretaría de Agricultura, Ganadería, Desarrollo Rural, Pesca y Alimentación. Servicio de Información Agroalimentaria y Pesquera. 2010. Available at: $<w w w . s i a p$. gob.mx/index>. Accessed on: June 212016.

SAIFULLAH, M.; MUHAMMAD, S.; LODHI, T.E. Communication gap regarding plant protection, harvesting and post-harvest technologies among the mango growers. Pakistan Journal of Agricultural Sciences, v.44, p.654-659, 2007.
SCHOEMAN, M.H.; MANICOM, B.Q.; WINGFIELD, M.J. Epidemiology of powdery mildew on mango blossoms. Plant Disease, v.79, p.524-528, 1995. DOI: 10.1094/PD-79-0524.

SINGH, R.S. Powdery mildew of mango. In: SINGH, R.S. Diseases of fruit crops. New Delhi: Oxford \& IBH Publishing, 2000. p.157-159.

SINHA, P.; CHAKRABARTI, U.; VARMA, A. Critical factors for mango powdery mildew development. Annals of Plant Protection Sciences, v.9, p.264-267, 2001.

SINHA, P.; VARMA, A. Statistical modeling forecasting of powdery mildews affecting agricultural crops; an overview. Journal of the Indian Society of Agricultural Statistics, v.57, p.257-270, 2004.

SMN. Servicio Meteorológico Nacional. 2017. Available at: $<$ http://smn.cna.gob.mx/es/informacion-climatologica-verestado?estado=gro $>$. Accessed on: July 202017.

TAHIR, H.A.S.; SAHI, S.T.; IQBAL, M.; SAHI, G.M.; ATIF, M. Evaluation of new fungicides against powdery mildew of mango (Mangifera indica). Pakistan Journal of Phytopathology, v.21, p.126-129, 2009.

TÉLIZ, D. (Ed.). EI mango y su manejo integrado en Michoacán. Montecillo: Colegio de Postgraduados, Grupo Interdisciplinario de Investigación en Mango, 1998.

THAL, W.M.; CAMPBELL, C.L.; MADDEN, L.V. Sensitivity of Weibull model parameter estimates to variation in simulated disease progression data. Phytopathology, v.74, p.1425-1430, 1984. DOI: 10.1094/Phyto-74-1425.

WICKS, T.J.; HITCH, C.J. Integration of strobilurins and other fungicides for the control of powdery mildew on grapes. Australian Journal of Grape and Wine Research, v.8, p.132139, 2002. DOI: 10.1111/j.1755-0238.2002.tb00222.x.

Received on November 26, 2016 and accepted on May 5, 2017 